\title{
SETTING UP THE STAGE FOR SMART SUSTAINABLE CITY: INTERNATIONAL AND UKRAINIAN CONTEXT. THE ROLE OF SMART SOLUTIONS
}

\author{
Anna Pozdniakova \\ Research Centre of Industrial Problems of Development of NAS of Ukraine \\ 1a, Inzhenernyy prov., 61166 Kharkiv, Ukraine, anna.pozdnyakova@p2h.com \\ (1) https://orcid.org/0000-0002-2589-7585 \\ Iryna Velska \\ The Eastern Partnership Civil Society Facility \\ 23-2505, Grygorenko Ave., 02068, Kiev, Ukraine, iryna.velska@eapcivilsociety.eu
}

\begin{abstract}
The paper analyzes the key steps taken by different cities worldwide and gathered into a clear step-by-step roadmap that can be useful for emerging smart cities. The Roadmap covers three main stages as we see them during the process of development: preparation, formation and spreading stages. We reveal how this is incorporated in the Ukrainian context.

Our analysis of smart city solutions from all over the world (based on the BeeSmartCity database) showed that the tech component on its own is not enough to overcome urban challenges within different domains (environment, economy, government etc.), as we see each of the solutions has a human component involved in a form of knowledge generation and sharing, different forms of co-creation and partnership etc. Thus, ICTs are a required but not a sufficient element of building successful citizen-friendly and resilient cities.
\end{abstract}

\section{Keywords}

Smart Sustainable city, ICT, sustainability, digitalization, Smart Solution, co-creation.

\section{Introduction}

Many international institutions (World Bank, UN etc.) consider information and communication technologies (ICT) as one of the possible tools that can help a society to overcome the urban challenges of the $21^{\text {st }}$ century, in particular: environmental degradation, the growing demand for limited resources, migration, the ageing of the population in some countries and the related growing demand for smart health solutions.

Research from the McKinsey Global Institute (MGI) in 2018 showed that the application of data and technologies in decision-making processes has allowed smart cities to reduce the crime rate by $30-40 \%$, decrease water consumption by $20-30 \%$ and accelerate emergency response time by $20-35 \%$ [1].

Smart cities represent a deep and multidisciplinary model, which aims to unite and use the synergy of the physical, digital, and human components. They are becoming a trend of the $21^{\text {st }}$ century among business and political stakeholders, as more cities claim their smartness and sustainability.

In recent years, the concept has evolved from the purely technology-led approach (Smart City 1.0) towards an inclusive and sustainable human-centered framework (Smart City 3.0) that aims to solve urban problems, and not just test new tech solutions.

The Smart City Concept is quite widespread topic among the academic sector as many prominent urbanists and economists study the topic, such as: B. Cohen, R. Giffinger, P. Lombardi, H. Schaffers, M. Rosenthal, and others. In addition, many international institutions are joining the academic sector in research and analysis, including IESE, ITU, OECD, and UN-Habitat along with such private sector representatives as Arcadis, Ericsson, and Huawei. In addition, there are many international platforms that aim to gather best practices and solutions to share the positive experiences among cities and communities, such as Bee Smart City, the European Innovation Partnership on Smart Cities and Communities (EIP-SCC), Idea bank of the Eastern Partnership Civil Society Facility etc.

In her article, Angelidou M. [3] analyses the types of Smart City Strategies and unites them into groups. She specifically studies the smart city strategies of 15 cities [24] worldwide in detail, confirming that most of them emphasize the role of ICTs failing to involve other important tools (co-creation and bottom-up approach). 
In our research, we aimed to outline the main components of the default Smart City Strategy and suggest the possible options within each component, i.e. objectives, principles, tools, models, stakeholders etc. Following the components, we created a step-by-step roadmap for any city aiming to become smart and sustainable. Apart from that, we presented the Ukrainian context and cities experience in building their digital agenda, solutions and platform that already work successfully.

Since smart applications are one of the widespread helping tools used to achieve the objectives of Smart Sustainable cities, many researchers (Angelidou M., Psaltoglou A., Komninos N.) and business companies (McKinsey Global Institute) aim to provide a qualitative and quantitative impact analysis of the latest.

\section{Methods}

In our research, we apply the methods of comparative analysis and generalization along with the methods of theoretical and systematic analysis of literature (both international and local smart solution libraries, smart city platforms, smart city strategies and plans, etc.).

The increased number of stakeholders led to an escalation of the amount of the generated Smart Solutions. To analyze the role of smart solutions in making our cities more citizen-centric and convenient, we selected a worldwide BeeSmartCity library of solutions. Reviewing 600+ smart solutions, we have outlined and summarized the issues they aim to address and enabling factors involved within different domains (economy, environment, people, government).

\section{Results and discussion}

Since 2014, more and more cities are engaging in the process of Smart city development. This includes both the development of a new strategy for a city, and introducing certain organizational and technical changes. The latest include, in particular:

- data opening (open data portals in Singapore, London, Chicago, Stockholm etc.),

- $\quad$ encouraging Civic Tech direction (Amsterdam Startup Residence, New York's NYCx Challenges, Civic Innovation Challenge London),

- support and encouragement of innovations,

- citizens digital readiness (providing access to ICTs, developing digital literacy and promoting digital engagement, improving digital safety),

- $\quad$ support for spreading digital solutions and working on common standards for digital services.

Cities typically start with a separate Smart City strategy, which is later integrated into the general city development strategy. This makes the model of the smart sustainable city just a tool to achieve a greater target.

There are also cities that still do not have formally accepted Smart City strategies like Amsterdam [2]. In the meantime, other countries might also accept nationwide strategies to ensure common standards between different cities and promote experience exchange on the national level. (The Netherlands, Singapore). Fig. 1. provides an overview of possible types of strategies along with their particular pros and cons. 


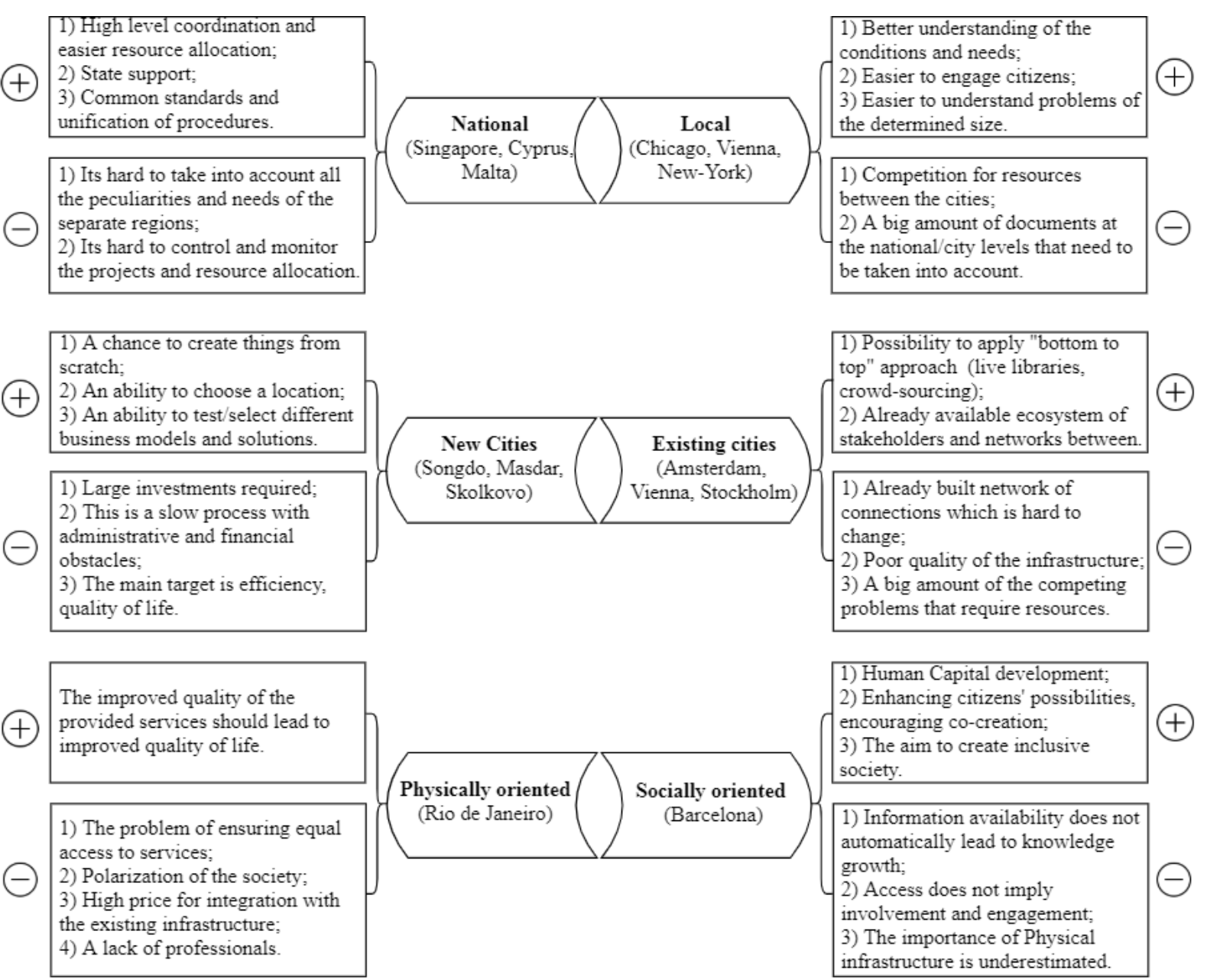

Fig. 1. Types of Smart City Strategies. Source: [3]

Local strategies are the most widespread since they allow local community needs to be addressed, and more flexible for new business models and solutions to be identified to engage citizens more actively. At the same time, national strategies are more widespread in small size homogeneous countries with minor economic diversification.

It is more time-consuming and expensive to create cities from scratch then to improve the existing cities. Apart from this, cities created from scratch have much higher risks of failure (they may be too expensive to live in, too complex to be used by people etc.).

So cities more often choose projects, which aim to regenerate their degraded territories to make them more convenient and comfortable for the users. Some cities place an emphasis on improving their physical infrastructure, investing in transport systems, energy, public utility services etc. Such cities hope that an enhanced range of the provided services will automatically result in a better quality of life. However, there are many questions regarding equal access to new services and problems of integration between the old and new infrastructure. Alongside there are cities that make a greater impact on the social component like Barcelona, investing more in knowledge growth, skills development, human capital and creativity, which, in its turn, will develop all other areas of life.

There are strategies that are focused on economic sectors, suggesting solutions for a particular sector such as energy, agriculture, industry etc., and strategies that focus on the geographical localization of clusters. Most cities want to involve all the stakeholders into a strategy development process, including citizens starting from public discussions to reach a common vision and set particular targets. 
As for the further model of organization and governance, typically cities establish a department for Smart cities within the municipality structure to connect all stakeholders, create a special position for Information and Digitalization Officer or/and establish a common public-private platform for communication (Vienna Smart City, London Smart city).

Financial models differ depending on the possible sources available for smart city projects. In general, we can outline the following:

- public financing, which implies the use of local or national tax revenues,

- $\quad$ private-public partnership, which involves the private sector to do the job and paid either from the budget or from future users' fees,

- crowdfunding,

- grants. [4].

While European cities typically rely on the local, national or EU budget, private investments are more popular in North America [5].

A project's size and associated risks influence the decision regarding the financial model, i.e. while crowdfunding, private sector philanthropy or special grant programs will be enough for small projects, middle size projects require venture capital and national funds, and big projects can involve national funds. Subsidies and state grants are a popular financial source, since many countries have nationwide challenges that allow cities compete for grants for particular projects, for example: Smart Cities Challenge India, Smart City Challenge Canada etc.

However, the private-public partnership remains one of the most widespread solutions. Crowdfunding is the rarest form to date, since municipalities do not have a clear understanding of how to use it.

The targets most cities set in their strategies can be roughly united into three groups:

economic (the desire to improve the quality and efficiency of services provided; further investments attracting, improving overall economic activity);

- $\quad$ social (ensuring inclusiveness, transparency of government bodies, increasing trust and citizens engagement),

- $\quad$ sustainable environment [5].

Among others, national strategies also include the following objectives:

- scaling up initiatives with good prospects,

- cooperation encouraging investments from the government and private sector,

- a more competitive position on the international market with the products and services that were successfully tested and applied within the country.

Our study of several smart city strategies allowed us to outline the following principles, which may contribute to the successful building of smart city concept:

- cooperation and coordination of efforts between the private, public, academic sectors and civil society,

- concept should be citizen-centered,

- data should be available and accessible,

- efficient resource management,

- the need for common standards during the development and implementation of smart city solutions;

- providing the opportunities and encouraging experience exchange on national and international levels,

- $\quad$ the importance of digital leadership and digital literacy.

Along with the strategy development, the most advanced cities are currently also setting up a separate platform for smart city projects and solutions (e.g. Amsterdam Smart City, Vienna Smart City etc.). 
The platform represents a space for discussion and communication between authority representatives, citizens, business and the academic sector. It allows for sharing news, providing feedback, discussing monitoring results and KPIs updates $[2,6]$.

There are also nationwide platforms for synchronization and experience exchange between cities (Smart City Sweden, Smart City Embassy in the Netherlands). Apart from this, cities also tend to unite going beyond just national boundaries $[7,8]$, like the following examples:

- The European Innovation Partnership on Smart Cities and Communities (EIP-SCC), a major EU-supported market-changing institution that brings together cities, industries, SMEs, investors, researchers [9],

- $\quad$ ASEAN Smart Cities Network (ASCN), a collaborative platform where cities from the ten ASEAN Member States (AMS) work towards the common goal of smart and sustainable urban development [10],

- Open and Agile Smart Cities, an international smart city network creating and shaping the global smart city data and services market of tomorrow [11],

- The Fab city, a global project to develop locally productive and globally connected self-sufficient cities. This a decentralized and open format project [12],

- The "United for Smart Sustainable Cities" (U4SSC), a UN initiative coordinated by ITU, UNECE and UNHabitat to achieve Sustainable Development Goal 11 [13].

According to the Future Cities Catapult analysis, these are believed to be the most widespread tools to establish and support Smart Sustainable Cities [5]:

- the use of ICTs, open data and analytics,

- networks and platforms,

- citizens engagement for generating innovative and crowdsourcing solutions,

- improving the basic infrastructure.

We have decided to investigate how those tools are used in real-life implemented solutions and what issues are aimed to be solved via provided technical solutions.

For this research, we have selected one of the largest worldwide databases for smart city solutions, BeeSmartCity. The network connects around 1,000 cities and already contains more than 600 solutions. BeeSmartCity also publishes its own Smart city ranking based on the number of Smart city solutions shared on the platform. At present Amsterdam, Moscow and Lublin are the top three cities in the ranking [14]. Below we have provided a breakdown of solutions by categories: smart economy, smart mobility, smart environment, smart governance, smart living, smart people (Fig. 2).

200

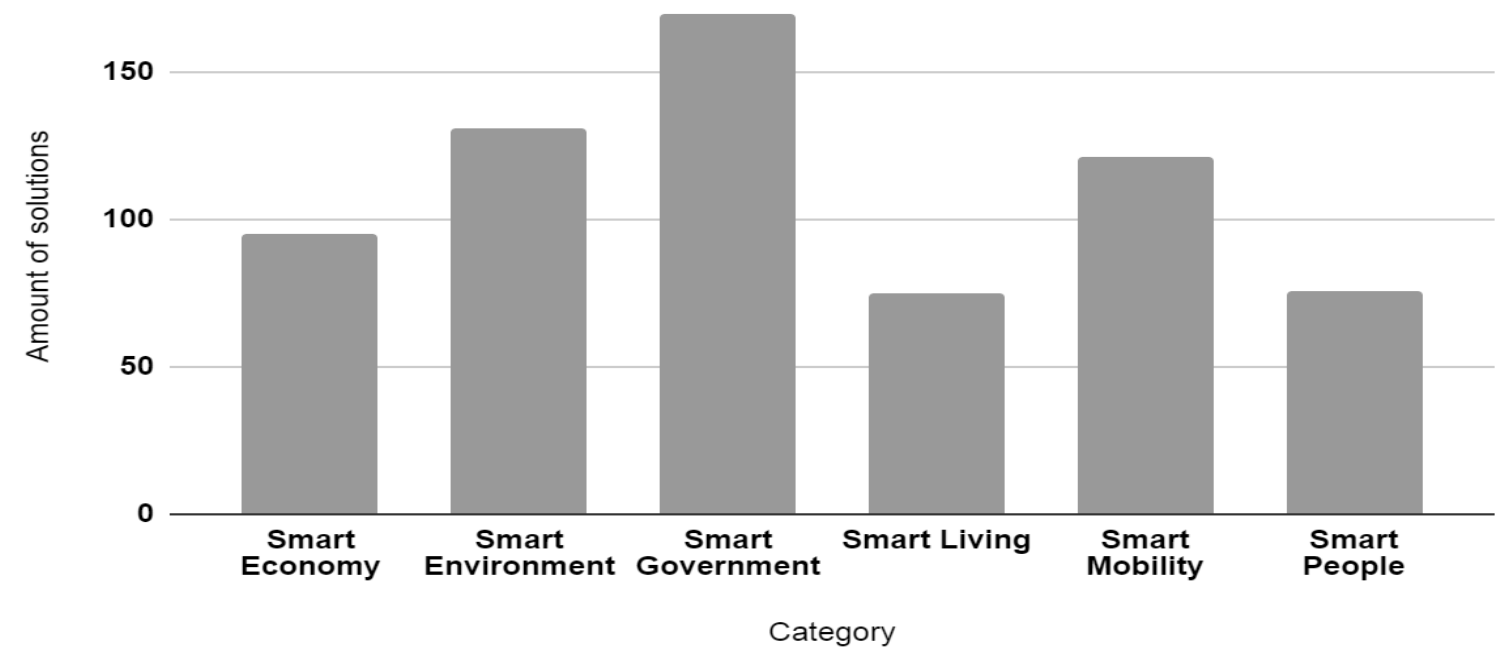

Fig. 2 Distribution of Smart Solutions from BeeSmartCity by areas of application. Source: Source: Own research based on [14] 
Most solutions presented on the platform belong to the Smart Governance category. Geographically, most solutions come from Europe (418), with North America being second (181). It is necessary, however, to keep data subjectivity in mind, as not all cities are active on the BeeSmartCity platform.

We have reviewed each of the solutions to identify:

- what issue the solution aims to solve,

- what smart solutions are available,

- what the innovative enablers of these solutions are (technology, process, approach).

The findings are summarized in the Fig. 3

\begin{tabular}{|c|c|c|c|}
\hline & Issue & Smart Solution & Enablers \\
\hline 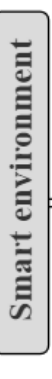 & $\begin{array}{l}\text { 1. Environment pollution. } \\
\text { 2. Wasting natural resources. } \\
\text { 3. Huge amounts of produced } \\
\text { and not re-cycled waste. } \\
\text { 4. High level of violence and } \\
\text { slow reaction. } \\
\text { 5. High level of } \mathrm{CO} 2 \text { emissions. }\end{array}$ & $\begin{array}{l}\text { 1.Platforms to measure the level of air, } \\
\text { water etc. pollution. } \\
\text { 2. Platforms to monitor the level of } \\
\text { resource consumption and wastage. } \\
\text { 3. Waste sorting, decreasing its } \\
\text { amount, re-cycling. } \\
\text { 4. Real-time digital alerts regarding } \\
\text { accidents. } \\
5 \text {. The usage of sharing and circular } \\
\text { economy elements. }\end{array}$ & $\begin{array}{l}\text { - Sensors; } \\
\text { - Networks; } \\
\text { - Internet of Things; } \\
\text { - Open Data; } \\
\text { - Web-technologies; } \\
\text { - Gamification; } \\
\text { - Citizens engagement. } \\
\text { Role of ICT: data sharing, } \\
\text { monitoring, integration. }\end{array}$ \\
\hline 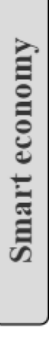 & $\begin{array}{l}\text { 1. The need to match producers } \\
\text { and consumers. } \\
\text { 2. The lack of resources. The } \\
\text { need to shift from ownership to } \\
\text { usage. } \\
\text { 3. Tourism development. } \\
\text { 4. Low level of entrepreneurial } \\
\text { activity. } \\
\text { 5. Unemployment. }\end{array}$ & $\begin{array}{l}\text { 1. Digital marketplaces. } \\
\text { 2. Sharing platforms. } \\
\text { 3. Mobile city guides and applications. } \\
\text { 4. Incubators for startups, platforms } \\
\text { for supporting entrepreneurs. } \\
\text { 5. Job fairs, online job search sites, } \\
\text { digital re-skill programs. }\end{array}$ & $\begin{array}{l}\text { - Web-technologies; } \\
\text { - VR; } \\
\text { - Hackathons; } \\
\text { - Public-private partnership. }\end{array}$ \\
\hline 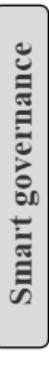 & $\begin{array}{l}\text { 1. Lack of convenient and } \\
\text { accessible communication } \\
\text { channels between authority and } \\
\text { citizens. } \\
\text { 2. Fast and convenient way to } \\
\text { receive administrative services. } \\
\text { 3. Old, neglected urban areas } \\
\text { which need renovations. } \\
\text { 4. Enhancing the rights and } \\
\text { opportunities of citizens. }\end{array}$ & $\begin{array}{l}\text { 1. Platforms and applications to notify } \\
\text { citizens about city news and events. } \\
\text { 2. Portal to receive administrative } \\
\text { services online. } \\
\text { 3. Portals for citizens to suggest their } \\
\text { ideas. Participatory budget. } \\
\text { 4. Platforms for submitting online } \\
\text { notifications about issues citizens } \\
\text { experience. }\end{array}$ & $\begin{array}{l}\text { - Web-technologies; } \\
\text { - Crowdsourcing and } \\
\text { Crowdsensing; } \\
\text { - Co-creation; } \\
\text { - Automation and } \\
\text { digitization of processes; } \\
\text { - Training of civil servants. } \\
\text { Role of ICT: data sharing, } \\
\text { connection. }\end{array}$ \\
\hline 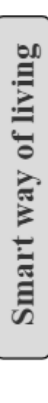 & $\begin{array}{l}\text { 1. Population Ageing. } \\
\text { 2. Timely first-aid help. } \\
\text { 3. Lack of the needed skills or } \\
\text { outdated skills. } \\
\text { 4. Inclusion of people with } \\
\text { disabilities. } \\
\text { 5. Medical services availability. } \\
\text { 6. Fragmentation of mobility } \\
\text { solutions (private and public). }\end{array}$ & $\begin{array}{l}\text { 1. Telemedicine. Remote health } \\
\text { monitoring. } \\
\text { 2. Applications for volunteers } \\
\text { notification about the help needed. } \\
\text { 3. Online courses. } \\
\text { 4. The program of inclusive studying } \\
\text { and employment. } \\
\text { 5. E-health. } \\
\text { 6. Mobile applications for planning the } \\
\text { roots which cover the data from } \\
\text { different operators. }\end{array}$ & $\begin{array}{l}\text { - Web-technologies; } \\
\text { - Sensors; } \\
\text { - Blockchain; } \\
\text { - Automation and } \\
\text { digitalization of processes; } \\
\text { - Citizen engagement; } \\
\text { - Public-private partnership; } \\
\text { - Social entrepreneurship. } \\
\text { Role of ICT: monitoring, } \\
\text { connection. }\end{array}$ \\
\hline
\end{tabular}

Fig. 3. The results of the analysis Issue - Solution - Enablers based on BeeSmartCity. Source: Source: Own research based on [14] 
The conducted analysis reveals that even though ICTs serve as one of the most widespread enablers for Smart Solutions, problem solving would be impossible without the human component involved in a form of knowledge generation and sharing, different forms of co-creation etc. Moreover, none of these solutions is needed unless the city has a proper physical infrastructure maintained in first order.

It's important to stress the crucial role digital sustainability plays in smart solutions development. With 'digital sustainability' we understand the development of solutions, which can be efficiently used during a long period of time. The end result should ensure user-friendly usage, easy future updates and integration with other solutions.

This is possible under the following conditions:

- establishing common standards for tech solutions,

- modular approach in development,

- ensuring a constant flow of information within and beyond the system,

- taking security into account; e) using inclusiveness by design.

Smart city concept is gaining in popularity in Ukrainian cities along with the worldwide trend due to a number of facts: active decentralization processes, growing number of IT specialists and active IT industry development, progressive society ready and craving for changes. The country plans to join the EU strategy for Smart Specialization, aiming each region to select its strongest and most promising industries.

We already have successful examples of smart solutions implemented, e.g. smart lighting project in Kropyvnytskyi, intellectual systems for mobility, e-gov solutions in a number of Ukrainian cities etc.

Moreover, we have cities that are working on developing the Smart City concept both in theory and in practice (Kyiv, Lviv, Kharkiv, Dnipro etc.). Most of them already have either a strategy for digital transformation (Lviv, Vinnytsia) or Smart city strategy (Kyiv, Dnipro Region). However, when compared to the European examples, current versions of strategies lack the needed level of details, KPIs, constant monitoring and progress sharing.

In 2016, the Hi-Tech Office Ukraine civil society organization was established. It unites the high tech companies that aim to create favorable conditions for innovative business and digital economy development in Ukraine. This organization contributes to the development of the "Digital Agenda of Ukraine 2020". The document discusses the main principles of digitalization, trends and challenges, along with the particular developments in different areas [15].

In 2019, the Ministry of Digital Transformation was established on the national level. It aims to create a "country in a smartphone" and is responsible for the state policy in the area of digitalization. The Ministry has the following targets to be achieved by 2024 : a) to provide $100 \%$ of public services online; b) $95 \%$ of transport infrastructure, cities, social objects should have an access to the fast internet; $c$ ) to involve 6 million Ukrainian citizens into the program of digital skills development; d) to increase the volume of IT sector in GDP up to 10\% [16].

The Ministry is currently working on the application called "Diya" ("Action"), which will cover the main services provided by the state to citizens and will allow direct communication between citizens and state, and actually envisages the "State in the smartphone" approach. The first step is a digital driver's license, which has been already launched in a test mode [16].

Unfortunately, to date only nine cities of Ukraine have joint the international Open Data Charter, despite the fact that accessible data is a key factor for the development of smart solutions that contributes to the improvement of citizens' life [17].

Cities can use their local budget funds, the public-private financial mechanism, EU grants and money of the State Regional Development Fund (SRDF). However, right now, only 30\% of the projects submitted for state funding belong to municipalities, and their quality leaves much to be desired [18].

We have only one city, which has developed and accepted the Smart City strategy (Kyiv Smart City in 2017). However, a number of cities have already established Reform Offices (Kharkiv, Dnipro) and instituted the corresponding positions for Officer of Digital Transformation (Kharkiv), and conduct forums for experience and 
knowledge exchange (Kharkiv Smart City forum, Kyiv Smart City Forum, Lviv 451 Forum). Hackathons and challenges for urban problems gain popularity both at the national and local levels.

NGO SocialBoost plays an important role in the process being an umbrella for startups, civic tech experts and government representatives who unite to address urban challenges and conduct annual hackathons. The organization developed the system of participatory budgets for municipalities, which is currently used in 32 cities and by 800 thousand citizens [19].

Another interesting initiative is the Dosvit project, which allows cities and united territorial communities to create modern, investor-friendly websites and add additional modules to them, like participatory budgeting, open budget, survey for citizens etc. [20].

In 2018, a project "E-services for amalgamated hromadas" was launched; representing a library of digital services used in different cities and amalgamated hromadas all over Ukraine. Right now, the system has around 300 solutions within different areas of life [21].

Also starting from 2018 the most popular services used by citizens of Ukraine have been united within one platform: e-dem.tools. It includes such services as e-petitions, participatory budgets, open city budget, and online consultations with citizens [22].

Though Ukrainian cities have done a lot in recent years to build smart and citizen-friendly cities, there is stillroom for improvement. Right now, we lack a holistic approach both on local and national levels regarding standards, ICT infrastructure, processes etc. Due to the fragmentary approach of each city, we risk to end up with a fully disintegrated national digital system [23]. In addition, the components of sustainability and smartness do not meet each other yet to serve as a tool and target accordingly.

We have created a roadmap for developing a Smart City Concept based on the performed analysis. 


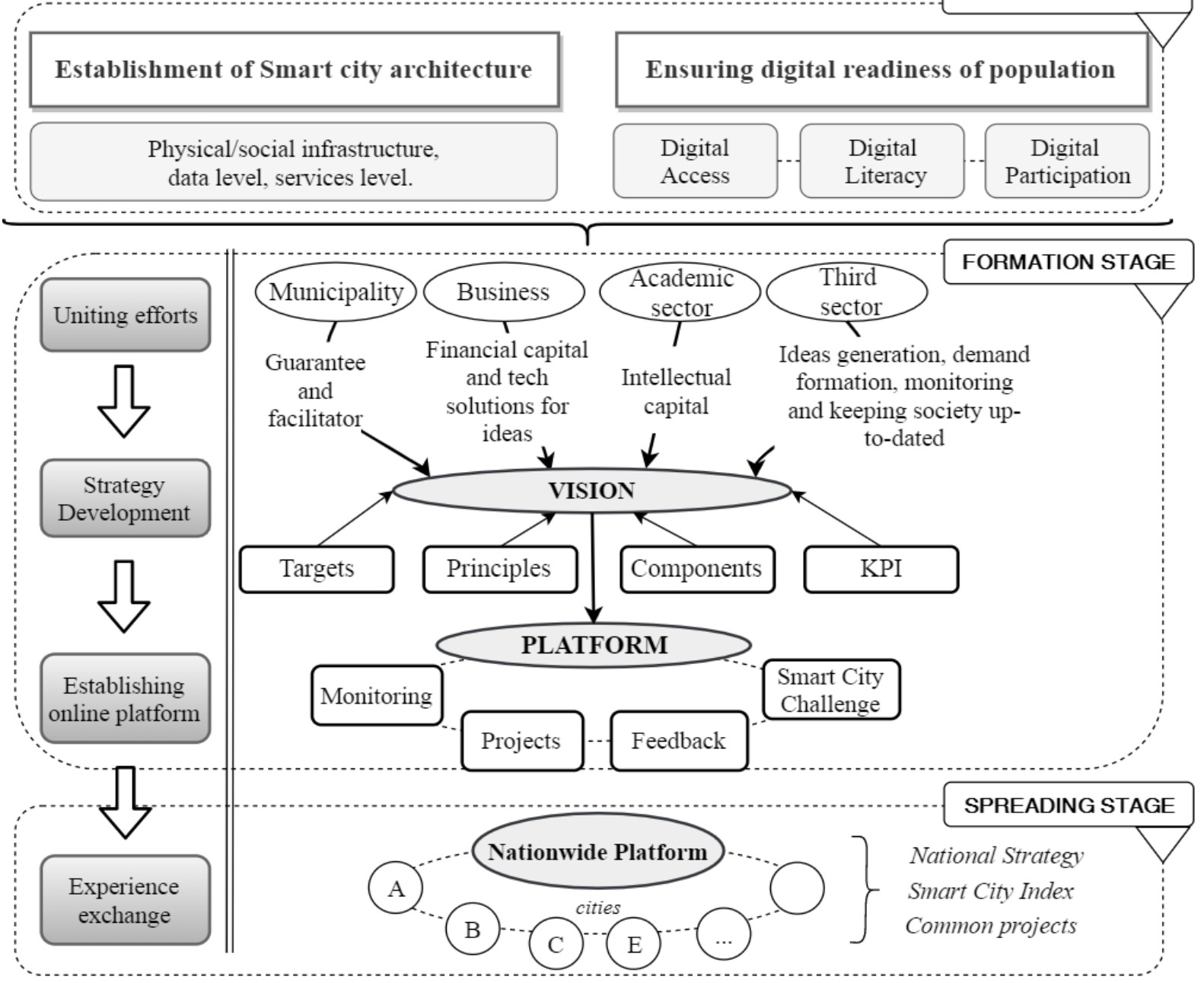

Fig. 4. Roadmap to develop Smart City Concept. Source: Source: Own research

We believe the process should have three stages.

During the preparation stage, a city needs to ensure that its citizens are ready for a new model of cooperation having both the needed digital skills and the possibility to apply them. At this stage, the required infrastructure needs to be prepared. This should cover both material and social components. A significant number of skilled professionals should be ready to work in a new environment and ensure its flawlessness. Communication and feedback are very important at this stage.

During the formation stage, cities aim to encourage cooperation based on a quadruple helix model involving all the stakeholders in search of a common vision of the city. The possible tools to be used are online surveys, round tables, voting etc.

At this stage, the responsible body should be established, like a reform office, department or new position within the municipality.

In result, the city should create a permanent platform and ensure that the community is involved in the process. Active citizens should engage in the process of co-creation through hackathons and competitions.

The spreading stage happens when cities have already set the vectors of development within their boundaries and have something to share with the world. A good idea would be to establish a national platform for experience 
exchange and "success stories" sharing. We believe at this stage, cities can start working on the National strategy and Smart City Index to compare and analyze the results of their work.

\section{Impact}

The provided step-by-step Roadmap for Smart city concept development based on the successful international experience will be useful for city development experts and municipalities that currently work on the agenda for their cities. We hope it contributes to a more integrated and efficient approach as well as to sustainability and proactivity of the newly developed strategies. This is especially relevant for Ukrainian cities, most of which are currently joining the movement of smart cities but do not have a well-structured approach and vision yet.

The analysis of the world library of smart solutions will help to identify the most relevant urban issues for each particular city and possible products that can be launched on the local level to address them. The listed enabling factors should help to understand the efforts and cooperation models required for each particular case. While business sector, which aims to take part in smart city projects (development, support etc.), can identify the closest domains to work in, develop a strategy and offer its services.

Overall, the research aims to transform the way our cities deal with urban challenges in the $21^{\text {st }}$ century, making the process more agile and efficient, encouraging new models of partnership and providing the theoretical foundation along with the practical recommendations.

Based on the research completed we believe these are the enabling factors that need to be taken into account by city development experts:

- Funding. It is important to think of possible tax exemptions for companies that work on smart city projects. Though this is not a widespread practice worldwide, many experts mention the need for it. Another point is to use the mechanism of crowdfunding more actively, involving citizens to the process of co-creation,

- Standardization. We believe it's important to develop common standards and best practices in the area of smart city projects, which will include software architecture requirements, data management standards etc.,

- Calls for ideas to engage stakeholders in urban problems solving. This implies data collection and its analysis, the involvement of citizens in the process of planning and consultation, active communication and feedback,

- Networking of cities for best practices exchange and good experience scaling,

- Open Data. Municipalities need to ensure data availability and access to it, the data should be provided in a format convenient for the users and developers, to be used,

- Human Capital Development, which is crucial to encourage the involvement of creative society and cocreation. Municipalities should pay attention to and ensure citizens' readiness for new technologies. STEM and multidisciplinary education are key directions,

- Technologies and IoT, which allow connecting all devices and a constant data exchange between them and the outside,

- Encouragement and support of living labs and science parks for generation, development and testing of new smart solutions and ideas,

- Partnership and cooperation between various stakeholders, both online and offline,

- Cyber Security, which implies the ability of the society to use the internet and other digital channels freely and safely, without risks to their privacy and free of cybercrimes. Specific recommendations would include: avoiding automation only control and always having a possibility of human control, and re-launching the system manually; establishing a position of a digital security officer, taking measures for digital hygiene among citizens etc. 
Obviously, there is no one-size-fits-all solution on how to make your city smart and sustainable but we have outlined above the enabling factors, which can be used in different combinations to achieve the goals in particular city sets.

\section{Conclusions}

Based on the research completed the following conclusions on smart city development can be drawn:

- Most cities choose the projects from a certain domain aiming to regenerate particular territories or to improve particular processes, making them more convenient for users. Since "a city built from scratch" model is typically associated with more risks and higher costs,

- There are several financial models available for smart city projects depending on their size and stakeholders involved but till the date public-private partnership stays the most widespread form, while the role of crowdfunding is underestimated,

- Most cities establish a separate department or position within the municipality responsible for the digitalization and development of a smart city framework, which helps to make the process more organized and efficient,

- Once a common vision, targets and principles are identified, cities should establish a platform that unites all stakeholders and is used to share the progress and KPIs, present the projects and provide the feedback,

- There is a tendency for a broader experience exchange on the national and international levels, which leads to city networking and close cooperation on particular projects. Typically, the model involves Lighthouse and Follower cities. Thus, cities should not work on smart concept development in isolation.

- Ukrainian cities have just recently started their journey, that is why their current approach is quite chaotic and disintegrated. Though many factors (e.g. decentralization, number of civic innovators and IT specialists etc.) along with the already undertaken steps (e.g. establishment of the Ministry of Digital Transformation and several local Reform offices, popularization of hackathons and smart city challenges, forums for experience sharing etc.) show the perspective of positive changes that should lead to a more coordinated, involving and holistic approach in developing the framework.

In addition, our study of smart city solutions from all over the world confirmed that tech component on its own is not enough to overcome urban challenges of the $21^{\text {st }}$ century. As we see, each of the solutions has a human component involved in the form of knowledge generation and sharing, different forms of co-creation and partnership, etc.

Moreover, none of these solutions is helpful unless a city has a proper physical infrastructure maintained firstly and digital literacy of the population ensured. Therefore, cities should focus on users' needs and ensure the solutions that they offer are suitable and convenient for citizens.

\section{Conflict of interest}

There are no conflicts to declare.

\section{Acknowledgments}

This research has not been supported by any external funding.

\section{References}

[1] McKinsey Global Institute. SMART CITIES: DIGITAL SOLUTIONS FOR A MORE LIVABLE FUTURE, 2018. Access mode: https://www.mckinsey.com/

[2] Amsterdam Smart City. Access mode: https://issuu.com/amsterdamsmartcity/docs/smart_stories

[3] Angelidou, M. Smart city policies: A spatial approach. Cities, 41, S3-S11. (2014). doi: 10.1016/j.cities.2014.06.007

[4] Funding and financing opportunities. Access mode: https://eu-smartcities.eu/sites/default/files/201806/4_EIP-SCC_BM\%26F\%20AC_Funding\%20and\%20financing\%20opportunities.pdf

[5] Smart city strategies: a global review. Access mode: http://futurecities.catapult.org.uk/wpcontent/uploads/2017/11/GRSCS-Final-Report.pdf 
[6] Wien Smart City projects. Access mode: https://smartcity.wien.gv.at/site/en/projects/

[7] The Smart City Strategy of The Netherlands. Access mode: https://smartcityhub.com/urban-planning-andbuilding/smart-city-strategy-netherlands/

[8] Smart city embassy. Access mode: http://www.smartcityembassy.nl/

[9] The Marketplace of the European Innovation Partnership on Smart Cities and Communities. Access mode: https://eu-smartcities.eu

[10] ASEAN Smart Cities Network. Access mode: https://asean.org/storage/2018/04/Concept-Note-of-theASEAN-Smart-Cities-Network.pdf

[11] Open and Agile Smart Cities. Access mode: https://oascities.org/about-oasc/

[12] The Fab city. Access mode: https://fab.city/

[13] United 4 Smart Sustainable cities. Access mode: https://www.itu.int/en/ITUT/ssc/united/Pages/default.aspx

[14] BeeSmartCity. Access mode: https://www.beesmart.city/

[15] Hi-tech office Ukraine. Access mode: http://www.ht-office.org/digital-agenda/

[16] Ministry of Digital Transformation. Access mode: https://thedigital.gov.ua/ministry

[17] The international Open Data Charter. Access mode: https://opendatacharter.net/

[18] Smart specialization implementation in Ukraine Access mode: https://www.kmu.gov.ua/ua/news/minregion-zaprovadit-smart-specializaciyu-regionalnogo-rozvitku-gennadijzubko

[19] SocialBoost. Access mode: http://socialboost.com.ua/

[20] Dosvit project. Access mode: http://dosvit.org.ua/

[21] E-gromadi. Access mode: https://cid.center/e-gromada/

[22] E-dem platform. Access mode: https://e-dem.tools/about_us

[23] Pozdniakova A.,DIGITALIZATION PROCESS IN UKRAINE AS A PREREQUISITE FOR THE SMART CITY CONCEPT DEVELOPMENT, The Baltic Journal of Economic Studies, 2017. DOI:10.30525/2256-0742/2017-3-4-206-215

[24] Angelidou M. The Role of Smart City Characteristics in the Plans of Fifteen Cities, Journal of Urban Technology, 2017. DOI:10.1080/10630732.2017.1348880 